\title{
Analisis Kandungan Nitrogen Tanah Sawah Menggunakan Spektrometer
}

\author{
Safirah Yuliani ${ }^{1}$, Daniel ${ }^{1}$ dan Mahmud Achmad ${ }^{1}$ \\ Program Studi Teknik Pertanian, Universitas Hasanuddin Makassar
}

\begin{abstract}
ABSTRAK
Tanah merupakan media tumbuh alami yang menyediakan makanan (unsur hara) bagi kelangsungan hidup tumbuh-tumbuhan (tanaman). Tanah yang memenuhi syarat agar pertumbuhan tanaman dapat optimal yang memiliki kandungan unsur hara yang cukup. Kandungan nitrogen pada tanah berbeda-beda tergantung pada karakteristik tanah. Penelitian ini bertujuan untuk untuk mengetahui korelasi kandungan nitrogen $(\mathrm{N})$ dengan nilai spektral, serta mengetahui ketersediaan hara (Kandungan Nitrogen) pada tanah yang dapat mempengaruhi produksi tanaman padi. Metode yang digunakan pada penelitian ini yaitu menggunakan speckrometer sebagai alat optik untuk menghasilkan garis spektrum cahaya dan mengukur panjang gelombang. Hasil pengukuran spektrometer inilah yang digunakan untuk mengidentifikasi kandungan unsur hara pada tanah dimana hanya dengan melihat gelombang pada warna tanah. Hasil penelitian ini menyimpulkan bahwa kandungan nitrogen pada lahan yang sama tapi cara pemupukan yang berbeda memiliki tingkat perbedaan yang tidak terlalu jauh berbeda. Hubungan kandungan nitrogen dengan nilai reflektansi mengatakan bahwa semakin tinggi kandungan nitrogen pada tanah maka nilai reflektansi semakin rendah begitu pula sebaliknya.
\end{abstract}

\section{PENDAHULUAN}

\section{Latar Belakang}

Indonesia memiliki tingkat produktivitas padi yang berbeda terhadap suatu lahan sawah dari tahun ke tahun. Kadang terjadi peningkatan dan penurunan hasil produksi gabah per petak sawah. Hal ini tergantung pada beberapa faktor, salah satunya faktor tanah. Tanah dipengaruhi oleh kandungan nitrogen yang terdapat didalamnya. Tanah merupakan media tumbuh alami yang menyediakan makanan (unsur hara) bagi kelangsungan hidup tumbuh-tumbuhan (tanaman). Agar tanaman mampu berproduksi secara optimal, kualitas tanah harus tetap dipertahankan. Kesalahan-kesalahan dalam pengolahan tanah dapat mengakibatkan kerusakan pada tanah, yang mengakibatkan turunnya produktivitas tanaman. Produktivitas tanah dalam menghasilkan produk pertanian sangat bergantung pada kemampuan suatu tanah dalam menyediakan unsur hara. $\begin{array}{ll}\text { Kandungan nutrisi pada tanah } \\ \text { berbeda-beda } & \text { bergantung }\end{array}$ karakteristik tanah. Karakteristik pada tanah ada dua yaitu tanah organik dan tanah non-organik. Tanah organik terbentuk dari pemadatan terhadap bahan organik yang terdegradasi. Tanah organik berwarna hitam dan merupakan pembentuk utama lahan gambutdan kelak dapat menjadi batu bara. Tanah organik cenderung memiliki keasaman tinggi karena mengandung beberapa asam organik hasil dekomposisi berbagai bahan organik. Sedangkan tanah non-organik didominasi oleh mineral, mineral ini membentuk partikel pembentuk tanah. Tekstur tanah non-organik ditentukan oleh komposisi tiga partikel pembentuk tanah seperti pasir, lanau (debu), dan lempung.

Pemupukan menggunakan pupuk kandungan nitrogen $(\mathrm{N})$ tinggi ternyata dapat menurunkan $\mathrm{pH}$ tanah sehingga tanah menjadi asam. Oleh karena itu, penggunaan pupuk kandungan $\mathrm{N}$ tinggi harus diimbangi dengan pengapuran yang 
tepat. Nitrogen $(\mathrm{N})$ merupakan bagian utuh dari struktur klorofil, warna hijau pucat atau kekuningan disebabkan kekahatan $\mathrm{N}$. Jika berlebihan unsur $\mathrm{N}$ akan merangsang pertumbuhan vegetatif, laju fotosintesis tinggi, penggunaan $\mathrm{CH}_{2} \mathrm{O}$ juga tinggi, akibatnya menghambat kematangan tanaman, jaringan menjadi sukulen, tanaman rebah, mudah terserang penyakit.

Untuk mendeteksi kandungan unsur hara pada tanaman dapat digunakan spektrometer. Spektrometer adalah sebuah alat optik untuk menghasilkan garis spektrumcahaya dan mengukur panjang gelombang serta intensitasnya. Spektrometer bekerja dengan menggunakan pantulan cahaya yang ditangkap menggunakan sensor yang dimana cahaya yang telah terdeteksi akan menghasilkan keluaran nilai spektral (grafik).

Berdasarkan uraian tersebut maka dilakukanlah penelitian terhadap kandungan nitrogen pada tanah untuk mengetahui bagaimana kandungan nitrogen mempengaruhi tingkat kesuburan pada tanaman, serta menganalisis warna tanah menggunakan buku Munsell Soil Color Chart.

\section{Tujuan dan Kegunaan}

Tujuan penelitian ini adalah untuk mengetahui korelasi kandungan nitrogen (N)dengannilaispektral, serta mengetahui ketersediaanhara (Kandungan Nitrogen) pada tanah yang dapat mempengaruhi produksi tanaman padi.

$\begin{array}{lrr}\text { Kegunaan penelitian ini } & \text { adalah } \\ \text { dapat mengembangkan } & \text { teknik } \\ \text { menganalisis kandungan } & \text { nitrogen } \\ \text { menggunakan spektrometer. } & \end{array}$

\section{TINJAUAN PUSTAKA}

\section{Pengertian Tanah}

Tanah adalah suatu benda alam yang terdapat dipermukaan kulit bumi, yang tersusun dari bahan-bahan mineral sebagai hasil pelapukan batuan, dan bahanbahan organik sebagai hasil pelapukan sisa-sisa tumbuhan dan hewan, yang merupakan medium atau tempat tumbuhnya tanaman dengan sifat-sifat tertentu, yang terjadi akibat dari pengaruh kombinasi faktor-faktor iklim, bahan induk, jasad hidup, bentuk wilayah dan lamanya waktu pembentukan (Oriska, 2012)

Struktur tanah merupakan suatu sifat fisik yang penting karena dapat mempengaruhi pertumbuhan tanaman serta tidak langsung berupa perbaikan peredaran air, udara dan panas, aktivitas jasad hidup tanah, tersedianya unsur hara bagi tanaman, perombakan bahan organik, dan mudah tidaknya akar dapat menembus tanah lebih dalam. Tanah yang berstruktur baik akan membantu berfungsinya faktorfaktor pertumbuhan tanaman secara optimal, sedangkan tanah yang berstruktur jelek akan menyebabkan terhambatnya pertumbuhan tanaman (Oriska, 2012).

\section{Nitrogen}

Menurut Oriska (2012), terdapat beberapa fungsi dari unsur nitrogen bagi tanaman yaitu sebagai berikut:

1. Untuk meningkatkan pertumbuhan tanaman.

2. Dapat menyehatkan pertumbuhan daun, daun tanaman lebar dengan warna

yang lebih hijau (pada daun muda berwarna kuning).

3. Meningkatkan kadar protein dalam tubuh tanaman. 
4. Meningkatkan kualitas tanaman penghasil daun-daunan.

5. Meningkatkan berkembangbiaknya mikroorganisme di dalam tanah.

Nitrogen diserap oleh akar tanaman dalam bentuk $\mathrm{NO}_{3}^{-}$(nitrat) dan $\mathrm{NH}_{4}{ }^{+}$ (amonium), akan tetapi nitrat ini akan segera tereduksi menjadi amonium. Kekurangan unsur Nitrogen dapat terlihat dari daunnya, warnanya yang hijau agak kekuningan yang kemudian berubah warna menjadi kuning lengkap. Jaringan daun mati, daun mati inilah yang menyebabkan daun menjadi kering dan berwarna merah kecoklatan. Pada tanaman dewasa pertumbuhan yang terhambat akan berpengaruh pada pembuahan, yang dimana perkembangan buah akan menjadi tidak sempurna, umumnya kecil-kecil dan cepat matang.Rendahnya kandungan unsur $\mathrm{N}$ dalam tanah dapat menghambat pertumbuhan tanaman. Tanaman yang mengalami kekahatan unsur $\mathrm{N}$, yang terdapat dalam jaringan tua akan diimobilisasi ke titik kemudian jaringan tua tersebut akan menguning, jika kekahatan terus berlanjut maka keseluruhan tanaman akan menguning, layu dan mati. Adapun dampak lainnya adalah mengakibatkan rendahnya produksi bobot kering tanaman (Nariratih, 2013).

\section{Siklus nitrogen}

Nitrogen sebagai nutrisi utama tanaman karena merupakan unsur penyusun protein, asam nukleat dan bahan organik lainnya. Jaringan tanaman yang sudah tua dan gugur, akan mengalami proses mineralisasi (amonifikasi) menjadi ion $\mathrm{NH}_{4}{ }^{+}$ dan imobilisasi (nitrifikasi) menjadi ion $\mathrm{NO}_{3}{ }^{-}$yang tersedia bagi tanaman (Nasaruddin, 2012).

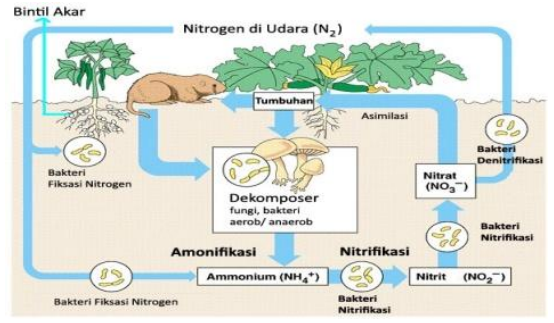

Gambar 1. Siklus nitrogen secara alami di alam

\section{Kandungan nitrogen pada tanah}

Kandungan nitrogen tanah bervariasi dari satu tempat ke tempat lainnya. Variasi kandungan nitrogen dalam tanah terjadi akibat perubahan topografi, disamping pengaruh iklim, jumlah kandungan nitrogen juga dipengaruhi oleh arah dan derajat lereng. Perbedaan kandungan nitrogen dalam tanah dapat dipengaruhi oleh erosi, pencucian melalui larutan, dan terangkut bersamaan dengan tanaman yang dipanen. Tingginya aliran permukaan dan erosi yang terjadi menyebabkan kehilangan hara yang terjadi juga akan semakin tinggi, karena pada lapisan tanah atas umumnya banyak mengandung unsur hara dan bahan organik (Junus, 2014).

\section{Pergerakan nitrogen pada tanah}

Nitrogen dapat dikatakan sebagai salah satu unsur hara yang bermuatan. Selain sangat mutlak di butuhkan, ia dengan mudah dapat hilang atau menjadi tidak tersedia bagi tanaman. Ketidak sediaan $\mathrm{N}$ dari dalam tanah dapat melalui proses pencucian (leaching) $\mathrm{NO}_{3}{ }^{-}$, denitrifikasi $\mathrm{NO}_{3}{ }^{-}$menjadi $\mathrm{N}_{2}$, volatilisasi $\mathrm{NH}_{4}{ }^{+}$menjadi $\mathrm{NH}_{3}$, terfiksasi oleh mineralliat atau dikonsumsi oleh mikroorganisme tanah. Bentuk $\mathrm{NO}_{3}^{-}$lah yang mudah larut, maka dikaji pergerakannya ke permukaan akar agar tidak hilang sehingga merupakan suatu usaha ke arab efisiensi pemupukan (Mukhlis, 2003) 


\section{Dinamika Kandungan Nitrogen Tanah}

Salah satu unsur hara yang penting adalah nitrogen $(\mathrm{N})$, yang harus diberikan secara teratur untuk menggantikan unsur hara yang ditambang dari tanah oleh tanaman. Penambahan pupuk nitrogen yang berlebihan ke dalam tanah, selain tidak ekonomis, juga dapat mencemari perairan. Penyerapan nitrogen oleh tanaman tergantung pada ketersediaan nitrogen dalam tanah. Ketersediaan nitrogen tersebut dapat dipengaruhi oleh proses kimia dan biologis. Dalam keadaan reduksi, $\mathrm{N}$ diserap tanaman dalam bentuk ammonium $\left(\mathrm{NH}_{4}{ }^{+}\right)$, sedangkan dalam keadaan oksidasi dalam bentuk nitrat $\left(\mathrm{NO}_{3}{ }^{-}\right.$) (Mulyani, 2000).

\section{Pupuk Agrimeth}

Agrimeth termasuk pupuk hayati yang mengandung bakteri penambat nitrogen simbiotik, nonsimbiotik, bakteri pelarut $\mathrm{P}$, dan bakteri penghasil fitohormon. Pupuk agrimeth dapat disimpan selama 6 bulan pada kondisi suhu lebih rendah dari suhu ruangan. Agrimeth cocok digunakan untuk tanaman kedelai, cabai dan padi. Pemberian pupuk hayati ini mampu meningkatkan hasil kedelai, padi, dan cabai di lahan masam dan nonmasam (Pratiwi, 2007).

\section{Spektrometer}

Spektrometer adalah instrumen yang digunakan untuk menghasilkan spektrum panjang gelombang cahaya, baik spektrum emisi, spektrum absorpsi, spektrum transmisi, spektrum reflektansi dan spektrum emisi dari sebuah objek (Novianty,2008).

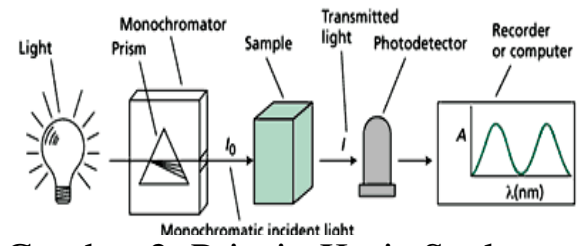

Gambar 2. Prinsip Kerja Spektrometer

Gambar diatas menunjukkan bahwa prinsip kerja spektrometer. Secara umum spectrometer terdiri dari sumber cahaya, pemilih panjang gelombang (wavelength selector) dan detektor. Sumber radiasi dapat berupa lampu incandescent dan lampu tungsten halogen. Lampu incandescent dapat menghasilkan spektra yang kontinyu dari panjang gelombang $350 \mathrm{~nm}$ hingga daerah NIR 2.5 $\mu \mathrm{m}$ (Novianty, 2008).

Nilai Reflektan Spektral (Spectral Reflectance, disebut spektra) merupakan perbandingan antara energi yang dipantulkan dengan energi yang sampai pada suatu objek sebagai fungsi panjang gelombang. Spektra merupakan suatu kwantitas tanpa unit yang mencakup harga dari 0 sampai 1.0 atau dapat juga dinyatakan sebagai persentase (Zulfiqar, 2016).

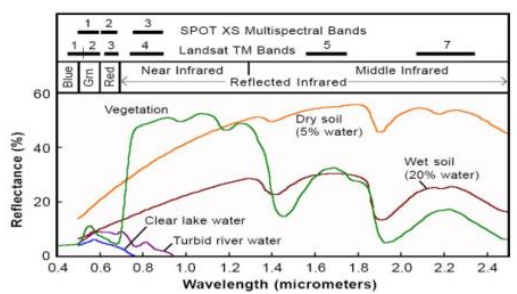

Gambar 3 Kurva Spektra terhadap Panjang Gelombang.

\section{Spectrawiz}

Spectrawiz (Stellar Net-Laser 2000) adalah program perangkat lunak utama yang berkaitan dengan spektrometer, dalam program spectrawiztelah banyak dibangun aplikasi untuk Spectro Radiometry, Spektrofotometri Colorimeter, Spectro Chemistry, Optical Analisis spektral, dan 
kalibrasi. SpectraWiz memungkinkan pengguna untuk mengubah berbagai parameter yang mengendalikan operasi spektrometer dan bagaimana data ditampilkan secara real- time. Sebagai contoh, tampilan spektral dapat diperbesar, snap shot, dicetak, digambarkan, diekspor, overlayed dan digambarkan dalam 3D (Suhaimi, 2015).

\section{CIE Lab}

CIE Lab merupakan model warna yang dirancang untuk menyerupai persepsi penglihatan manusia dengan menggunakan tiga komponen yaitu L sebagai luminance (pencahayaan), a dan b sebagai dimensi warna yang berlawanan. Perancangan sistem aplikasi ini menggunakan model warna CIE Lab pada proses segmentasi dan proses color moments. Color moments merupakan metode yang cukup baik dalam pengenalan ciri warna.Model warna ini dipilih karena terbukti memberikan hasil yang lebih baik daripada model warna RGB dalam mengukur nilai kemiripan ciri warna terhadap objek (Indrayani, 2012).

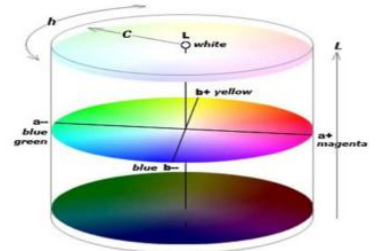

Gambar 4. CIE Lab Color Model

\section{Warna Tanah}

Warna merupakan petunjuk untuk beberapa sifat tanah. Warna hitam menunjukkan kandungan bahan organik tinggi. Warna merah menunjukkan adanya oksida besi bebas (tanah-tanah yang teroksidasi). Warna abu-abu kebiruan menunjukkan adanya reduksi. Warna disusun oleh tiga variabel yaitu hue, value, dan kroma. Hue adalah warna spectrum yang dominan, sesuai dengan panjang gelombang. Value menunjukkan gelap terangnya warna, sesuai dengan banyaknya sinar yang dipantulkan. Kroma menunjukkan kemurnian atau kekuatan dari warna spectrum (Hardjowigeno, 2003).

Tabel 1. Kandungan Mineral dan Kecenderungan Warna Tanah

\begin{tabular}{|c|c|c|}
\hline Mineral & Mumsell & Warna \\
\hline Goethite & 10 YR 8/6 & Kuning \\
\hline Goethite & 7.5 YR 5/6 & Coklat yang kuat \\
\hline Biji besi & 5R 3/6 & Merah \\
\hline Biji besi & $10 \mathrm{R} 4 / 8$ & Merah \\
\hline Lepidocrocite & 5 YR 6/8 & $\begin{array}{c}\text { Kemerahan } \\
\text { kuning }\end{array}$ \\
\hline Lepidocrocite & 2.5 YR 4/6 & Merah \\
\hline Ferihidrit & 2.5 YR 3/6 & Merah gelap \\
\hline Glauconite & 5Y 5/1 & Abu-abu gelap \\
\hline Besi sulfida & 10 YR 2/1 & Hitam \\
\hline Pirit & 10 YR 2/1 & Hitam (logam) \\
\hline Jarosit & 5Y 6/4 & Kuning pucat \\
\hline Todorokite & 10 YR 2/1 & Hitam \\
\hline Humus & 10 YR 2/1 & Hitam \\
\hline Kalsit & 10 YR 8/2 & Putih \\
\hline Dolomit & 10 YR 8/2 & Putih \\
\hline Gips & 10 YR 8/3 & $\begin{array}{c}\text { Coklat sangat } \\
\text { pucat }\end{array}$ \\
\hline Kuarsa & 10 YR 6/1 & Abu-abu muda \\
\hline
\end{tabular}

\section{Hubungan Antara Kandungan Nitrogen Dengan Reflektansi}

Hubungan reflektansi dan bahan organik memiliki parameter yang berbeda pada seluruh daerah spektral. Sedangkan kandungan nitrogen memiliki respon spektral yang khas pada flap panjang gelombang tertentu. Berdasarkan hasil studi dapat diketahui bahwa hubungan nilai spektral reflektansi dengan kandungan nitrogen mempunyai hubungan linier yang kuat pada panjang gelombang $660 \mathrm{~nm}$ pada spektrometer (Wiyudha, 2003).

\section{METODE PENELITIAN}

\section{Waktu dan Tempat}

Penelitian Analisis Kandungan Nitrogen pada Tanah Sawah Menggunakan Spektrometer dilaksanakan mulai bulan Mei - Agustus 2016 bertempat di Desa 
Alatengae Kecamatan Bantimurung Kabupaten Maros.

\section{Alat dan Bahan}

Alat yang digunakan adalah laptop, spektrometer, softwareSpectrawiz, plastik sampel, cawan petri, spidol.

Bahan yang digunakan adalah sampel tanah basah yang diperoleh dari lahan persawahan Desa Alatengae Kecamatan Bantimurung Kabupaten Maros, dan kertas label.

\section{Prosedur Kerja}

Penelitian Analisis Kandungan

Nitrogen Pada Tanah Menggunakan Spektrometer ini

\section{a. Pengambilan Data Reflektansi Lapangan}

1. Menentukan petak sawah yang akan diambil sampel tanahnya. Pengambilan tanah ini berdasarkan dosis pemupukan yang berbeda pada setiap petak sawahyang telah dibagi menjadi 4 petakan pada beberapa cara pemupukan, agar dapat dilihat perbedaan kandungan nitrogen tanahnya :

- Cara 1 Pupuk Standar (Urea, SP 36, ZA, Ponska, dan Humit Acid)

- Cara 2 Pupuk Standar (100\%) + Agrimeth (500gram untuk $25 \mathrm{~kg}$ benih/hektar)

- Cara 3 Pupuk Standar (75\%) + Agrimeth (500gram untuk $25 \mathrm{~kg}$ benih/hektar)

- Cara 4 Pupuk Standar (50\%) + Agrimetth (500gram untuk $25 \mathrm{~kg}$ benih/hektar)

2. Mengambil sampel tanah dalam keadaan basah pada petak sawah yang telah ditentukan.

Sampel yang diambil berupa tanah yang basah sekitar \pm 200 gram kemudian dimasukkan kedalam cawan petri.

3. Mengukur reflektansi pada sampel tanah yang telah diambil menggunakan spektrometer.

Tanah yang telah diambil kemudian diukur reflektansinya menggunakan spektrometer yang dimana pantulan cahaya tersebut akan ditangkap melalui sensor, kemudian keluarannya menghasilkan nilai spektral (grafik).

4. Menganalisis warna tanah menggunakan Munsell Soil Color Chart. Tanah yang telah diukur reflektansinya menggunakan spektrometer kemudian tanah tersebut di analisis warna tanahnya menggunakan buku Munsell Soil Color Chart(Macbeth, New Windsor USA).

5. Menganalisis korelasi kandungan nitrogen dengan produktivitas Menganalisis dan membandingkan kandungan nitrogen pada tanah dari masing-masing petak sawah yang telah diambil sampel tanahnya dan produktivitas tanaman pada lahan sawah

\section{b. Proses Pengukuran Nitrogen di Laboratorium}

1. Mengeringkan tanah sampai kering

2. Setelah proses pengeringan tanah, memasukkan $10 \mathrm{ml}$ ekstrak sampel ke dalam labu didih

3. Menambahkan serbuk batu didih dan aquades hingga setengah volume labu

4. Menyiapkan penampung $\mathrm{NH}_{3}$ yang dibebaskan yaitu erlenmeyer yang berisi $10 \mathrm{ml}$ asam borat $1 \%$ yang ditambah dua tetes indikator 
Convay (berwarna merah) dan dihubungkan dengan alat destilasi

5. Dengan gelas ukur, tambahkan $\mathrm{NaOH} 40 \%$ sebanyak $10 \mathrm{ml}$ ke dalam labu didih yang berisi contoh dan secepatnya ditutup

6. Didestilasi hingga volume penampung mencapi 50-75 $\mathrm{ml}$ (berwarna hijau)

7. Destilat dititrasi dengan $\mathrm{H}_{2} \mathrm{SO}_{4}$ $0,050 \mathrm{~N}$ hingga warna merah muda.

8. Mencatat volume titar contoh $\left(\mathrm{V}_{\mathrm{c}}\right)$ dan blanko $\left(\mathrm{V}_{\mathrm{b}}\right)$.

9. Setelahpengukurandilakukan maka dapat diketahui kandungan nitrogen pada tanah

10. Menganalisis korelasi kandungan nitrogen dengan nilai spectral

\section{c. Pengukuran Reflektansi Tanah di Ruangan}

1. Tanah hasil pengukuran lapangan di simpan di ruangan kemudian di keringkan udara

2. Setelah tanah kering udara maka tanah tersebut dijenuhkan kembali

3. Dalam kondisi jenuh tanah diukur reflektansinya menggunakan spektrometer

\section{Diagram Alir Penelitian}

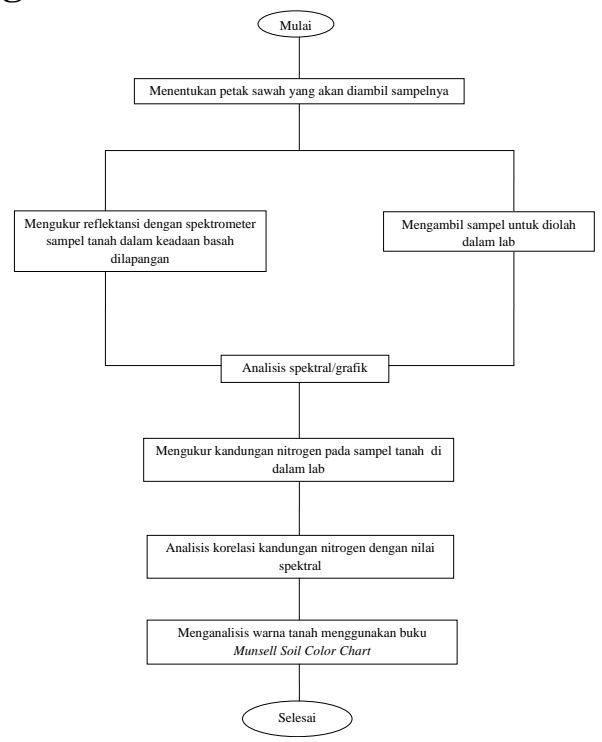

Gambar 5. Diagram Alir Penelitian
HASIL DAN PEMBAHASAN

Keadaan Umum Lokasi

Desa Alatengngae Kecamatan

Bantimurung Kabupaten Maros merupakan salah satu penghasil beras terbesar di Sulawesi Selatan. Areal persawahan di Bantimurung mencapai 25 hektar dan menjadi persawahan terluas di Kabupaten Maros. Di Desa Alatengngae tersebut mencapai hasil panen antara 6,00 sampai 9,00 ton/hektar.

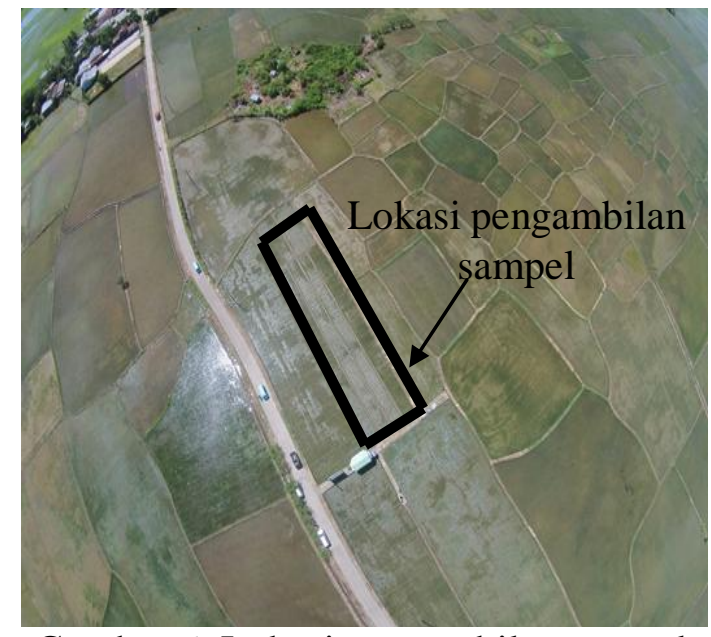

Gambar 6. Lokasi pengambilan sampel

tanah

Keadaan umum lokasi terletak di Desa Alatengngae Kecamatan Bantimurung Kabupaten Maros. Letak geografis area ini yaitu terletak di bagain barat Sulawesi Selatan antara $40^{\circ} 45^{\prime}$ $50^{0} 07^{\prime}$ Lintang Selatan dan $109^{0} 205^{\circ}$ $129^{0} 12^{\prime}$ Bujur Timur. Luas lahan tempat pengambilan sampel tanah seluas 13.5 are dan panjang lahan 55 meter. Lahan tempat pengambilan sampel ini berada pada lahan nomor 152 dimana lahan sawah dibagi menjadi 4 petakan.

\section{Analisis Kandungan Nitrogen}

\section{Kandungan Nitrogen Tanah}

Kandungan nitrogen pada tanah merupakan unsur utama bagi pertumbuhan tanaman yang pada umumnya sangat diperlukan untuk 
pembentukan atau pertumbuhan bagian vegetatif pada tanaman.

Tabel 2. Kandungan nitrogen tanah pada berbagai perlakuan pemupukan.

\begin{tabular}{|c|c|c|c|c|}
\hline \multirow{2}{*}{ HST } & \multicolumn{4}{|c|}{ Kandungan Nitrogen Tanah ( $\%$ bb) } \\
\hline & Cara 1 & Cara 2 & Cara 3 & Cara 4 \\
\hline $\begin{array}{l}\text { (HST 11 } \\
\text { hari) } \\
\text { Sebelum } \\
\text { Pupuk }\end{array}$ & 0.12 & 0.12 & 0.10 & 0.11 \\
\hline $\begin{array}{c}\text { (HST } 30 \\
\text { hari) } \\
\text { Setelah } \\
\text { Pupuk }\end{array}$ & 0.23 & 0.23 & 0.20 & 0.21 \\
\hline $\begin{array}{c}\text { (HST 40 } \\
\text { hari) } \\
\text { Sebelum } \\
\text { Berbunga }\end{array}$ & 0.22 & 0.26 & 0.24 & 0.25 \\
\hline $\begin{array}{c}\text { (HST } 60 \\
\text { hari) } \\
\text { Setelah } \\
\text { Berbunga }\end{array}$ & 0.20 & 0.25 & 0.22 & 0.26 \\
\hline $\begin{array}{c}\text { (HST 70 } \\
\text { hari) } \\
\text { Padi Berisi }\end{array}$ & 0.29 & 0.30 & 0.25 & 0.23 \\
\hline $\begin{array}{c}\text { (HST 85 } \\
\text { han) } \\
\text { Pematangan }\end{array}$ & 0.24 & 0.36 & 0.32 & 0.29 \\
\hline $\begin{array}{c}\text { (HST 95 } \\
\text { han) } \\
\text { Panen }\end{array}$ & 0.22 & 0.22 & 0.23 & 0.24 \\
\hline Rata-rata & 0.22 & 0.25 & 0.22 & 0.23 \\
\hline
\end{tabular}

Berdasarkan Tabel 2 dapat dilihat bahwa sebelum pemupukan kandungan nitrogen rendah dan saat padi berisi sampai pematangan kandungan nitrogen meningkat. Kandungan nitrogen yang paling tinggi setelah di rata-ratakan adalah cara 2 yaitu 0.25 yang dimana petakan tersebut dilakukan perlakukan penambahan pupuk Agrimeth dan pupuk non-organik ditetapkan dosisnya $100 \%$, sedangkan yang terendah data 1 yaitu 0.22 dimana pada petakan tersebut tidak ditambahkan pupuk Agrimeth dan juga dilakukan pengurangan dosis pupuk non-organik 25\%. Pupuk Agrimeth dapat meningkatkan kandungan nitrogen pada tanah dan juga dapat meningkatkan hasil produktivitas tanaman padi.

\section{Kandungan Nitrogen selama masa} Pertumbuhan

Pupuk nitrogen diperkirakan banyak yang hilang karena terbawa aliran permukaan (run-off), menguap (volatilization), dan meresap ke bawah (leaching).Penambahan pupuk nitrogen yang berlebihan ke dalam tanah, selain tidak ekonomis, juga dapatmencemari perairan. Penyerapan nitrogen oleh tanaman tergantung pada ketersediaan nitrogen dalam tanah. Ketersediaan nitrogen tersebut dapat dipengaruhi oleh proses kimia dan biologis.Kehilangan nitrogen melalui penguapan mencapai $70 \%$ tergantung pada KTK tanah dan tinggi genangan. Kehilangan nitrogen yang demikian tinggi tersebut menyebabkan hanya $10 \%$ saja yang diserap tanaman.

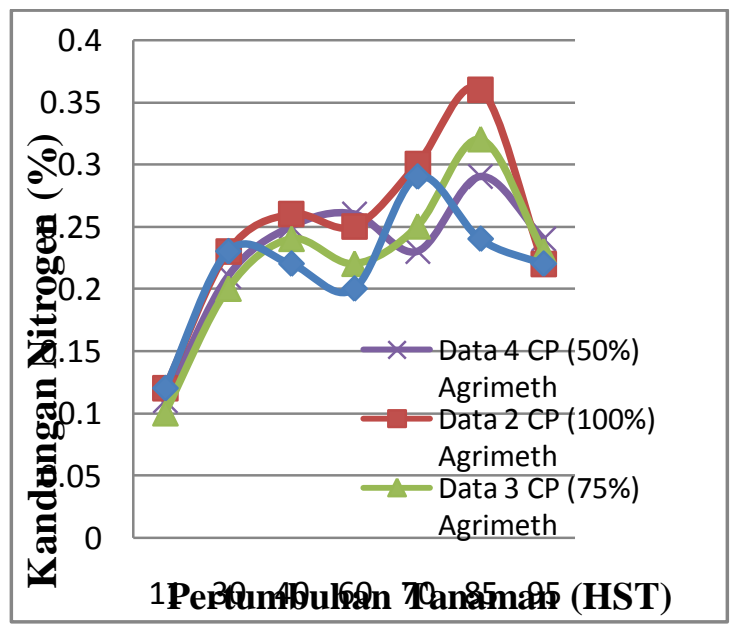

Gambar 7. Dinamika kandungan nitrogen tanah selama pertumbuhan

Gambar 7 menunjukkan bahwa terjadi peningkatan dan penurunan kandungan nitrogen selama masa pertumbuhan padi. Peningkatan kandungan nitrogen disebabkan adanya tambahan pupuk hayati lain yaitu Agrimeth dan juga pupuk Agrimeth ini dapat menyebabkan penambatan kandungan nitrogen tanah apabila pemberian dosisnya berlebih. 
Cara pertama pada pemupukan standar, dimana terjadi penurunan kandungan nitrogen yang cukup banyak dikarenakan tidak dilakukan pemberian pupuk Agrimeth. Kandungan nitrogen juga menurun disebabkan karena pada awal pertumbuhan tanaman kadar air tanah mulai berkurang. Pada masa padi berisi kandungan nitrogen mulai meningkat dan menurun saat pematangan padi sampai pemanenan dikarenakan jaringan tanaman yang sudah tua mengalami proses mineralisasi sehingga sebagian besar $\mathrm{N}$ mengalami denitrifikasi dan lepas ke udara dalam bentuk $\mathrm{N}_{2}$.

Cara kedua pada pemupukan standar (100\%) + Agrimeth, terjadi peningkatan kandungan nitrogen di awal pertumbuhan tanaman dan penurunan yang sangat sedikit disebabkan karena tingginya dosis pupuk non-organik. Pemberian pupuk Agrimeth menyebabkan kandungan nitrogen pada petakan ini meningkat dan peningkatan yang cukup tinggi terjadi pada masa pematangan padi.

Cara ketiga pada pemupukan standar $(75 \%)+$ Agrimeth, terdapat persamaan bentuk grafik tapi kandungan nitrogen pada cara pemupukan kedua lebih tinggi dibandingkan cara pemupukan ketiga. Hal ini disebabkan karena perbedaan dosis pemupukan pada kedua petakan sawah.

Cara keempat pada pemupukan standar $(50 \%)+$ Agrimeth, terdapat perbedaan peningkatan kandungan nitrogen pada masa setelah berbunga sedangkan data yang lain terjadi penurunan kandungan nitrogen. Penyebab terjadinya kandungan nitrogen meningkat salah satu karena dosis pemupukan pupuk hayati hanya $50 \%$, dimana pupuk juga memiliki $\mathrm{N}$ yang tinggi apabila pemberian dosis pupuk pada tanaman cukup tinggi pula maka akan mempengaruhi tingkat kandungan nitrogen tanah.

\section{Perbandingan antara Rata-rata} Kandungan Nitrogen dengan Data Hasil Panen

Kandungan nitrogen tanah bervariasi dari satu tempat ke tempat lainnya. Kandungan unsur $\mathrm{N}$ yang rendah pada tanaman dewasa menimbulkan pertumbuhan terhambat dan berpengaruh pada pembuahan.

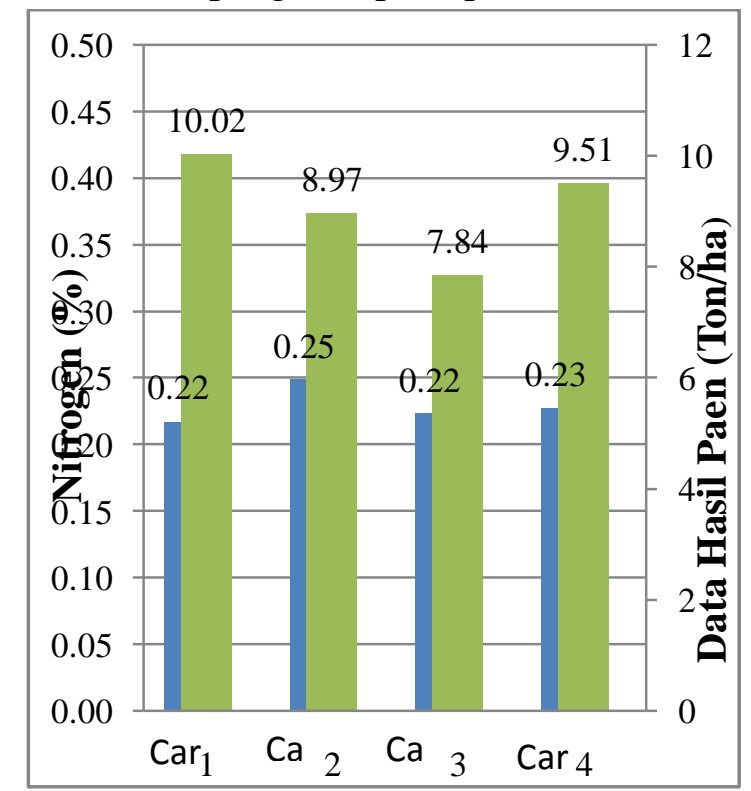

Gambar 8. Perbandingan rata-rata kandungan nitrogen dengan hasil panen

Gambar 8 menunjukkan bahwa petakan sawah yang memiliki kandungan nitrogen terendah menghasilkan produktivitas tertinggi yaitu 10.02 ton/hektar, hal ini dikarenakan tidak menggunakan pupuk Agrimeth dimana pupuk tersebut sebagai penambat tanah. Petakan yang menghasilkan produktivitas terendah $\mathrm{CP} 2$ 
(100\%)Agrimeth dan CP 3 (75\%)Agrimeth yaitu 8.97 ton/hektar dan 7.84 ton/hektar, dikarenakan terserang hama wereng coklat sekitar 50-75\%. Petakan yang menggunakan dosis pemupukan $\mathrm{CP}(50 \%)$ Agrimeth menunjukkan hasil panen yang cukup tinggi karena mendapatkan limpasan air dari petakan sebelah.

\section{Analisis Reflektansi}

\section{Hasil Pengukuran Reflektansi di Lapangan (Insitu)}

Kekhasan masing-masing hasil dari pengukuran lapangan memiliki range reflektansi panjang gelombang dari tinggi ke rendah, yang ditunjukkan pada gambar di bawah ini.

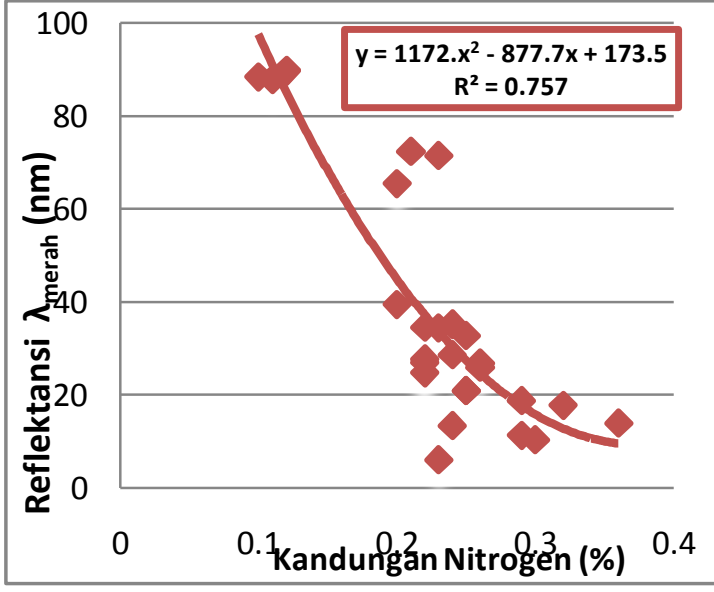

Gambar 9. Hubungan reflektansi dengankandungan nitrogen pada panjang gelombang merah (di lapangan).

Berdasarkan Gambar 9 dapat dilihat bahwa telah diukur reflektansi tanah menggunakan spektrometer. Sampel yang diukur berupa tanah dalam keadaan basah pada lahan sawah 152. Nilai reflektansi diperoleh dari hasil pengukuran menggunakan spektrometer. Hasil hubungan keduanya dapat dilihat pada Gambar 9. Pada Gambar tersebut hubungan dari data keduanya mencapai nilai $\mathrm{R}^{2}$ validitas 0.7576 yang menandakan bahwa nilai tersebut hampir akurat karena hampir mencapai 1. Sehingga dapat dikatakan bahwa panjang gelombang pada $\mathrm{R}$ paling baik dalam menentukan tingkat kandungan nitrogen.

Pada Gambar 9 ini menunjukkan bahwa titik yang mendekati garis trendline berarti akurat sedangkan yang tidak mendekati berarti tidak akurat. Nilai reflektansi dengan kandungan nitrogen pada panjang gelombang $\mathrm{R}$ mempunyai kekuratan yang kuat. Hal ini sesuai dengan pendapat (Wiyudha, 2003) berdasarkan hasil studi dapat diketahui bahwa hubungan nilai spektral reflektansi dengan kandungan nitrogen mempunyai hubungan linier yang kuat pada panjang gelombang $660 \mathrm{~nm}$ pada spektrometer.

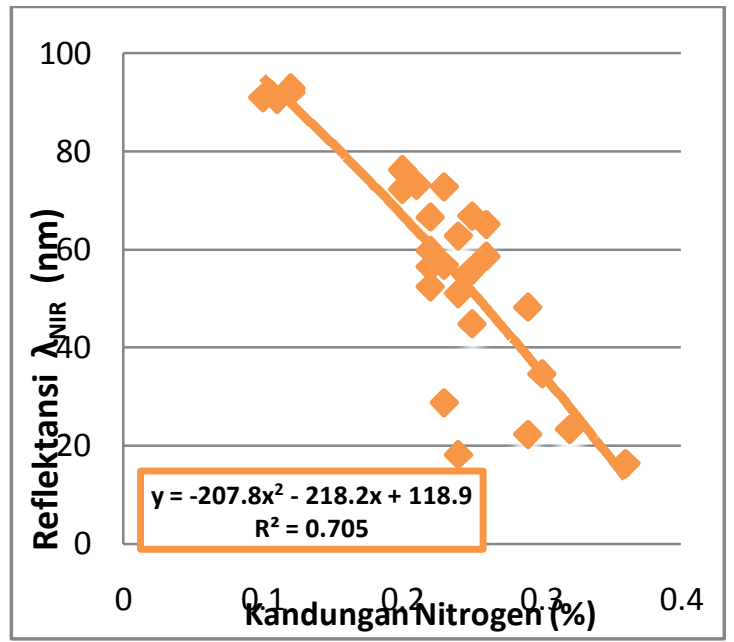

Gambar 10. Hubungan reflektansi dengan kandungan nitrogen pada panjang gelombang NIR (di lapangan).

Berdasarkan Gambar 10 menunjukkan bahwa grafik berbeda dengan grafik dari panjang gelombang ketiganya, karena memiliki nilai reflektansi yang cukup besar setelah nilai $\mathrm{R}^{2}$ validitas pada panjang gelombang $\mathrm{R}$. Nilai $\mathrm{R}^{2}$ validitas pada 
panjang gelombang NIR mencapai 0.7054. Reflektansi yang diperoleh berasal dari pengukuran di lapangan menggunakan alat spektrometer. Spektrometer mengambil data reflektansi dari pantulan cahaya yang ditangkap menggunakan sensor dimana cahaya yang telah terdeteksi akan menghasilkan keluaran nilai spectral (grafik). Setelah hasil dari reflektansi diketahui, dihubungkanlah dengan nilai kandungan nitrogen yang terdapat pada tanah yang berada di lahan nomor 152.

Gambar 10 menunjukkan grafik hubungan antara keduanya. Dari Gambar tersebut dapat dilihat bahwa kedua pengukuran tersebut mendapatkan keakuratan hingga mencapai 0.7054 yang menandakan bahwa pengukuran tersebut mendekati angka 1. Hal tersebut menandakan bahwa hasil nilai $\mathrm{R}^{2}$ validitas yang diukur dari kedua pengukuran tersebut hampir akurat. Sehingga dapat dikatakan bahwa semakin tinggi kandungan nitrogen maka semakin rendah nilai reflektansi begitupun sebaliknya.

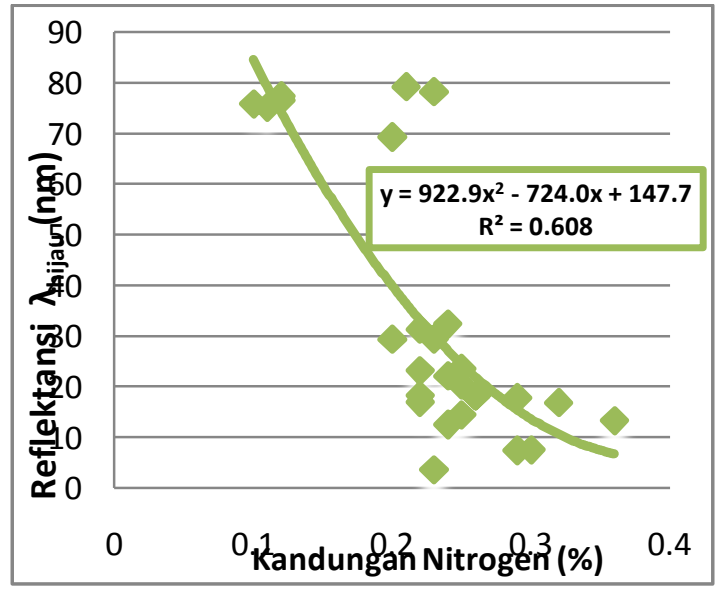

Gambar 11. Hubungan reflektansi dengan kandungan nitrogen pada panjang gelombang hijau (di lapangan).
Berdasarkan Gambar 11 dapat dilihat hubungan reflektansi dengan kandungan nitrogen. Pada Gambar 11 menunjukkan kecenderungan grafik yang sama dengan grafik pada panjang gelombang B. Nilai korelasi pada panjang gelombang $\mathrm{G}$ lebih tinggi dibandingkan panjang gelombang $\mathrm{B}$. Nilai reflektansi yang diperoleh dari pengukuran lapangan menggunakan spektrometer ini memiliki tingkat keakuratan yang tidak mendekati angka 1. Nilai $\mathrm{R}^{2}$ validitas pada panjang gelombang hijau mencapai 0.6085 .

Pada Gambar ini juga menunjukkan bahwa titik-titik kandungan nitrogen tanah banyak yang tidak mendekati garis trendline. Nilai dari hubungan reflektansi dan kandungan nitrogen pada panjang gelombang $G$ tidak mempunyai nilai keakuratan yang kuat, tidak sama dengan panjang gelombang $\mathrm{R}$ dimana nilai $\mathrm{R}^{2}$ validitasnya mendekati angka 1. Jadi dapat dikatakan bahwa panjang gelombang $\mathrm{G}$ belum tentu baik dalam menentukan tingkat kandungan nitrogen pada tanah sawah.

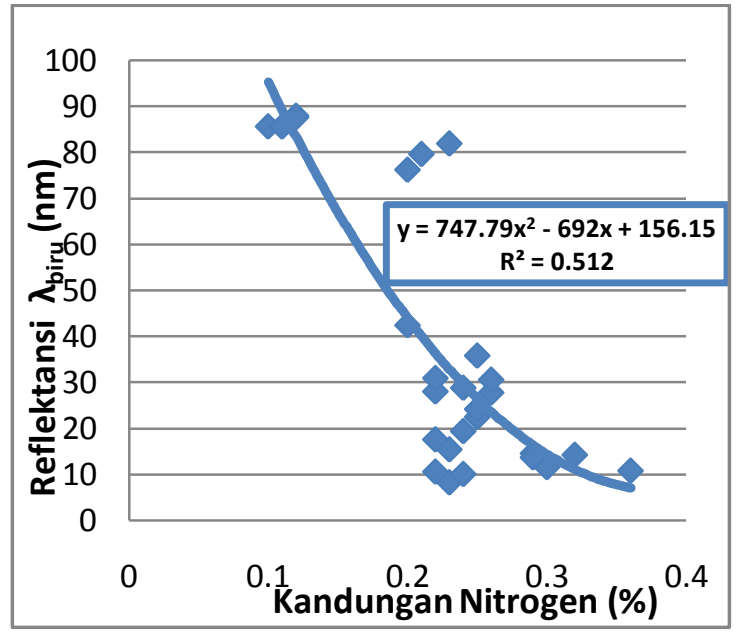

Gambar 12. Hubungan reflektansi dengan kandungan nitrogen pada panjang gelombang biru (di lapangan). 
Gambar 12 menunjukkan bahwa panjang gelombang $\mathrm{B}$ yang memiliki nilai korelasi paling rendah diantara keempat panjang gelombang. Nilai $\mathrm{R}^{2}$ validitas pada panjang gelombang biru mencapai 0.512. Jika dilihat dari nilai $\mathrm{R}^{2}$ validitas pada semua panjang gelombang menunjukkan bahwa panjang gelombang $\mathrm{R}$ memiliki nilai $\mathrm{R}^{2}$ validitas tertinggi dibandingkan pada panjang gelombang G, B, dan NIR. Sedangkan nilai $\mathrm{R}^{2}$ validitas pada panjang gelombang $\mathrm{B}$ sangat kecil. Sehingga dapat dikatakan bahwa panjang gelombang pada $\mathrm{R}$ yang paling baik dalam menentukan tingkat kandungan nitrogen.

Tingkat keakuratan pada panjang gelombang B belum akurat jika dilihat dari titik-titik pada grafik yang sangat jauh dari garis trendline, dan dapat dikatakan bahwa hubungan reflektansi dengan kandungan nitrogen pada panjang gelombang B tidak baik dalam menentukan tingkat kandungan nitrogen pada tanah sawah mulai dari proses pertumbuhan tanaman sampai produksi tanaman. Hubungan antara reflektansi dengan kandungan nitrogen tanah sawah dalam kondisi basah pada panjang gelombang R,G,B, dan NIR menunjukkan bahwa semakin rendah kandungan nitrogen maka semakin tinggi nilai reflektansi begitu pula sebaliknya.

\section{Pengukuran Reflektansi Tanah di Ruangan}

Setelah semua sampel tanah dari hasil pengukuran lapangan telah terkumpul maka sampel tersebut disimpan di ruangan kemudian dibiarkan kering angin dan dijenuhkan kembali sebelum pengukuran reflektansi

di ruangan.

Hasil pengukuran reflektansi tanah pada kondisi jenuh ditunjukkan pada Gambar 13-16.

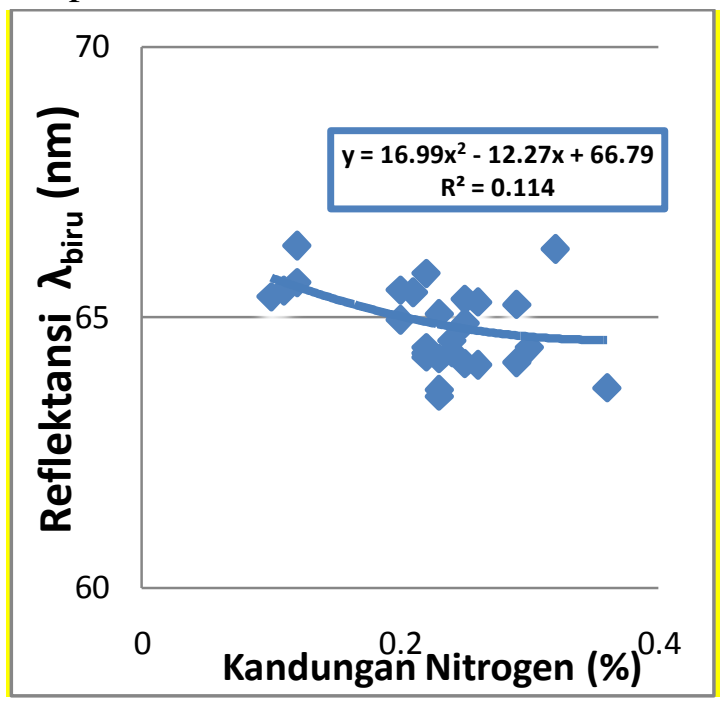

Gambar 13. Hubungan reflektansi dengan kandungan nitrogen pada panjang gelombang biru (di ruangan).

Pada Gambar 13 menunjukan hubungan antara reflektansi dan kandungan nitrogen tidak dapat di jadikan landasan untuk melihat kandungan nitrogen pada tanah. Hal ini disebabkan korelasi antara reflektansi dan kandungan nitrogen tidak menunjukan hasil yang bagus untuk melihat kandunganya. Hal ini dapat di lihat dari nilai $\mathrm{R}^{2}$ validitas yang sangat kecil sekitar 0,1143 pada grafik perbandingannya.

Tingkat keakuratan pada gambar ini sangat rendah dikarenakan nilai $\mathrm{R}^{2}$ validitas tidak mendekati angka keakuratan pada umumnya. Reflektansi tanah pada panjang gelombang B tidak memiliki hubungan dengan kandungan nitrogen awal sebelum tanah dikeringkan dan dijenuhkan kembali. 


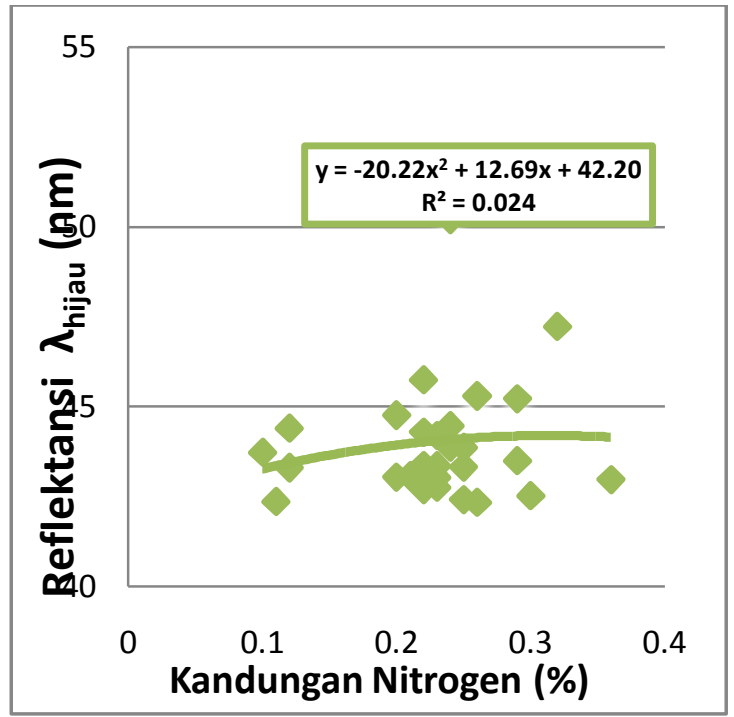

Gambar 14. Hubungan reflektansi dengan kandungan nitrogen pada panjang gelombang hijau (di ruangan).

Berdasarkan Gambar 14 dapat dilihat hubungan reflektansi dengan kandungan nitrogen pada pengukuran ruangan. Pada Gambar 14 menunjukkan kecenderungan grafik yang tidak sama dengan grafik pada ketiga panjang gelombang. Nilai reflektansi pada grafik ini juga sangat rendah dibandingkan pengukuran reflektansi dilapangan. Nilai reflektansi yang diperoleh dari pengukuran ruangan setelah dijenuhkan kembali menggunakan spektrometer ini memiliki tingkat keakuratan yang sangat jauh dari angkat 1 . Pada gambar ini juga menunjukkan bahwa titik-titik kandungan nitrogen tanah banyak yang tidak mendekati garis trendline.

Pada Gambar 14 juga menunjukkan hasil yang sama pada Gambar 13 dimana perbandingan antara reflektansi dan kandungan nitrogen tidak dapat dijadikan landasan dalam menarik sebuah hasil yang sesuai untuk melihat hubungan keduanya. Dimana nilai $\mathrm{R}^{2}$ validitas pada panjang gelombang green hanya 0,0246 sangat jauh dari titik ideal.

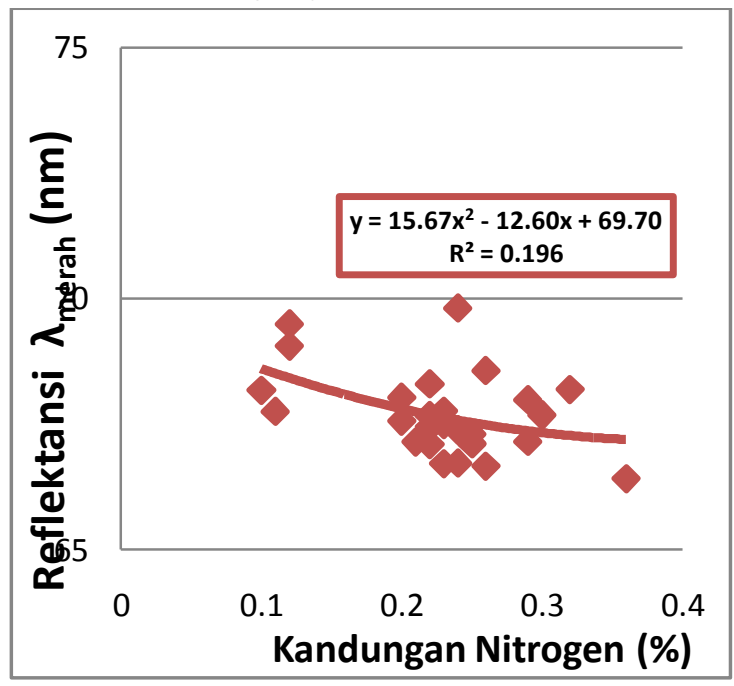

Gambar 15. Hubungan reflektansi dengan kandungan nitrogen pada panjang gelombang merah (di ruangan).

Pengukuran ruangan sangat beda jauh nilai $\mathrm{R}^{2}$ validitas dengan pengukuran dilapangan. Perbedaan dapat diliat dari nilai reflektansi dan kandungan nitrogen yang tidak diukur kembali setelah pengukuran di ruangan, hal ini dikarenakan pengukuran reflektansi di ruangan untuk mengetahui perbandingan reflektansi di lapangan. pengukuran di ruangan dilakukan hanya sebagai pembanding.

Pada Gambar 15 yang menunjukan panjang gelombang red juga menunjukan nilai $R^{2}$ validitas yang sangat kecil sehingga nilai yang di harapkan untuk menunjukan keseuaian antara nilai reflektansi dan kandungan nitrogen tidak begitu jelas dan sangat sulit untuk di jadikan landasan dalam menilai hubungan keduanya. Nilai $\mathrm{R}^{2}$ validitas pada panjang gelombang $\mathrm{R}$ bisa dikatakan tidak akurat dan tidak cocok dalam penentuan tingkat kandungan nitrogen. 


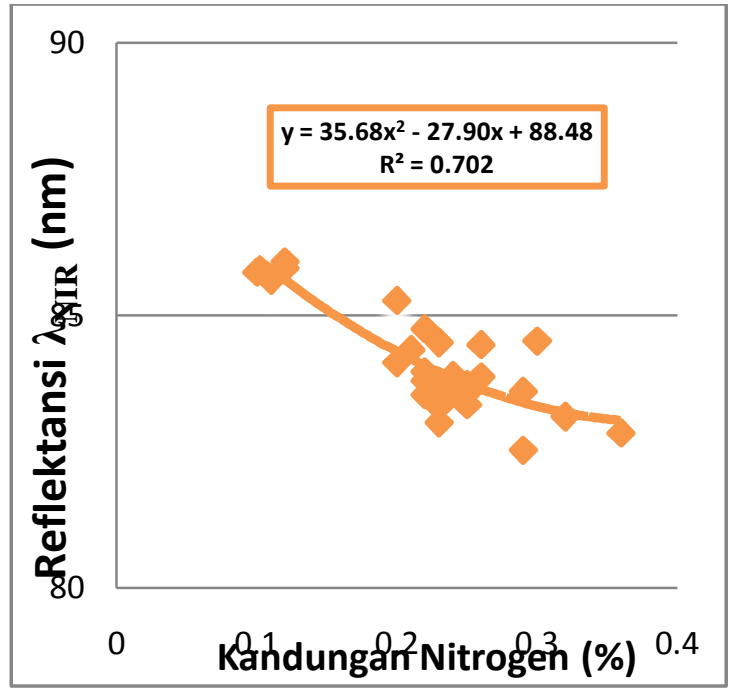

Gambar 16. Hubungan reflektansi dengan kandungan nitrogen pada panjang gelombang NIR (di ruangan).

Sedangkan pada Gambar 16 dengan menilai pada panjang gelombang NIR adalah panjang gelombang spesifik yang sangat sesuai digunakan pada penentuan nitrogen baik di lapangan maupun di ruangan. Nilai $R^{2}$ validitas pada panjang gelombang NIR paling tinggi mencapai $(0,7029)$ diantara nilai $R^{2}$ validitas dari panjang gelombang ketiganya. Hal ini disebabkan karena rendahnya korelasi antara keempat panjang gelombang. Keempat panjang gelombang mempunyai data yang sangat berbeda. Perbedaan tersebut terlihat dari grafik dan nilai $\mathrm{R}^{2}$ validitas.

Hasil pengukuran sampel di laboratorium menunjukkan bahwa perbedaan yang sangat signifikan terhadap hasil pengukuran di lapangan, perbedaannya terdapat pada kandungan nitrogen tanah kering dan yang dijenuhkan kembali. Pengukuran di ruangan dilakukan hanya untuk mengetahui reflektansi tanah setelah dikeringkan apakah masih mempunyai hubungan dengan kandungan nitrogen awal, dan dilakukan pengukuran hanya sebagai pembanding.

\section{KESIMPULAN}

\section{Kesimpulan}

Dari hasil pengukuran reflektansi dan kandungan nitrogen tanah diperoleh kesimpulan sebagai berikut:

1. Kandungan nitrogen dapat diprediksi menggunakan reflektansi.

2. Kelebihan kandungan nitrogen pada tanah tidak menyebabkan terjadinya penurunan hasil produksi.

3. Hubungan antara reflektansi lapangan dengan ruangan tidak menunjukkan korelasi.

\section{DAFTAR PUSTAKA}

Hardjowigeno, S. 2003. Ilmu Tanah. Penerbit Akademika Pressindo. Jakarta.

Indrayani. 2012. Model Pengeringan Lapisan Tipis Temu Putih. Skripsi. Jurusan Teknologi Pertanian. Universitas Hasanuddin: Makassar.

Junus, Y. 2014. Kandungan Nitrogen Tanah. Universitas Negeri Gunadarma: Jakarta.

Mukhlis, Sariffudin dan H Hanum. 2011. Kimia Tanah. Teori dan Aplikasi.USU Press. Universitas Sumatera Utara: Medan.

Mulyani. 2000. Dinamika Hara Nitrogen Pada Tanah Sawah. Pusat Penelitian dan Pengembangan Tanah dan Agroklimat: Bogor

Nariratih, I. 2013. Ketersediaan Nitrogen Pada Tiga Jenis Tanah Akibat Pemberian Tiga Bahan Organik dan Serapannya Pada Tanaman Jangung. Jurusan Agroteknologi. Universitas Sumatera Utara: Medan.

Nasaruddin. 2012. Nutrisi Tanaman. Masagena Press. Makassar. 
Novianty, I. 2008. Analisa Spektroskopi Reflektans Vis-Nir Untuk Mengetahui Proses Pematangan Buah Stroberi.Skripsi. Fakultas Matematika dan Ilmu Pengetahuan Alam: Bogor.

Oriska, R. 2012. Tanah. Universitas Negeri Yogyakarta: Yogyakarta.

Pratiwi, I. 2007. Pupuk Agrimeth. Balai Pengelola Air Teknologi Pertanian (BPATP): Bogor.

Suhaimi. 2015. Studi Tentang Kondisi Cekaman Air Bibit Tanaman Kakao (Theobroma Cacao L) dan Hubungannya dengan Reflektansi Tanaman. Skripsi. Fakultas Pertanian. Universitas Hasanuddin: Makassar.

Wiyudha. 2003. Analisis Hubungan Nilai Spektral Reflektansi dengan Kandungan Nitrogen pada Tanaman Padi menggunakan Spektormeter dikaitkan dengan Citra Satelit Landsat ETM 7. Institut Teknologi Bandung. Bandung.

Zulfikar. 2016. Analisis Kandungan C Organik Dan Kadar Air Pada Tanah Berdasarkan Reflektansi. Skripsi. Fakultas Pertanian. Universitas Hasanuddin: Makassar. 